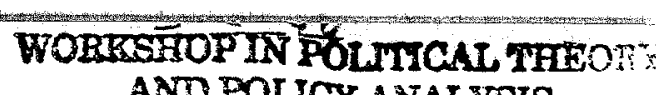
AND POLICY ANALYSIS 513 NORTH PARK INDLNNA UNIVERSITY BEOQMINGTON, IN 47408-3895 U.SA - Ch - M

\title{
FOREST RESOURCES IN A NEPALI VILLAGE IN 1980 AND 1990: THE POSITIVE INFLUENCE OF POPULATION GROWTH
}

\author{
JEFFERSON Fox \\ Program on Enzrironment \\ -East-West Center

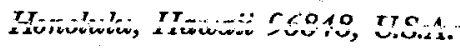

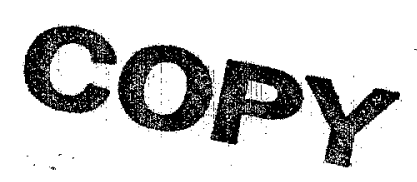

ABSTRACT This paper describes changes in forest condition and forest management practices in a Nepali village between 1980 and 1990, and attempts to identify the factors behind these changes. In 1980-81 the author spent a year studying forest-use practices and forest products in a village in the Middle. Hills of central Nepal. Species composition, density (tree/ha), and tree size (basal area) were described. The quantity of forest products collected from forest lands was measured. Weekly accounts were kept from a sample of households on the amount of firewood and fodder collected, and the number of hours animals were grazed. In 1990 the author returned to the same village to resurvey forest lands and io assess changes in forest-use practices. Despite an annual population growth rate of $2.5 \%$, forests were found to be in much better condition in 1990 than they were in 1980 .

RÉSUMÉ Gestion des forêts dans un village népalais: l'influence positive de la cưiissance démographique. Cet article décrit les changements qui se sont produits entre 1980 et 1990 dans un village népalais, du point de vue de la condition des forêts et des pratiques de gestion de celles-ci, et essaie d'identifier les factors qui ont contribué à cts thangements.

En 1980-81, l'auteur a passé une année à étudier les pratiques d'exploitation des forêts et les produits forestiers dans un village du Moyen Himalaya dans le Népal central. La distribution des espèces, la densité en nombre d'arbres par hectare et la taille des arbres (zone basale) sont décrites dans cet article. La production des terres forestières a été mesurée à l'aide de registres tenus pour un certain nombre de familles. Ces registres indiquent la quantité de bois de chauffage et de fourrage récoltée chaque semaine, ainsi que le nombres d'heures pendant lesquelles le bétail était au pâtturage. En 1990, l'auteur est retourné dans le même village dans le but d'examiner de nouveau les terres forestières et d'évaluer les changements de pratiques d'exploitation des terres. En dépit d'une croissance démographique de 2,5 pour cent par an, les forêts étaient en bien meilleure condition en 1990 qu'elles
ne l'étaient en 1980 .

ZUSAMMENFASSUNG Waldmanagement in einem nepalesischen Dorf: Der positive Einfluß des Bevölkerungswachstums. Dieser Artikel beschreibt Veränderungen in der Waldbeschaffenheit und im Waldmanagement eines nepalesischen Dorfes in den Jahren zwischen 1980 und 1990; und versucht, die den Veränderungen zugrunde liegenden Faktoren zu identifizieren. Der Autor verbrachte 1980/81 ein Jahr in einem Dorf der Middle Hills in Zentralnepal, um Methoden der Waldnutzung und die Waldprodukte zu untersuchen. Die Artenzusammensetzung, Dichte (Bäume/ha) und der Baumumfang (an der Basis) werden beschrieben. Außerdem wurden die Waldprodukte, die auf den bewaldeten Flächen gesammelt wurden, quantitativ erfaßt. Ausgewählte Haushaltungen lègten wöchentlich Rechenschaft darüber ab, wieviel Feuerholz und Viehfutter gesammelt wurden und wie lange das Vieh weidete. Im Jahre 1990 kehrte der Autor in dasselbe Dorf zurück, um die Waldflächen neu zu inspizieren und Veränderungen in der Waldnutzung zu beurteilen. Trotz einer jährlichen Bevölkerungswachstumsrate von $2,5 \%$, fand er die Waldgebiete 1990 in besserem
Zustand als im Jahre 1980 .

\section{INTRODUCTION}

Since the early 1970s numerous authors have written about deforestation in Nepal as a result of uncontrolled use of forest lands by a rapidly growing rural population (Eckholm, 1976; Bishop, 1978; Hoffpauir, 1978). More recently other authors have begun to document examples of successful conservation and forest management efforts (see Messerschmidt, 1990; Stone, 1990; Fisher, 1991; Gilmour, 1991). What happened? Were the reports in the 1970s and early 1980s erroneous, or did they fail to predict how Nepali farmers would react to forest degradation and to shortages of forest products? Gilmour (1989) argues that there is an increased likelihood of indigenous forest management systems developing where forest products are relatively inaccessible. Is this the answer? $\mathrm{Had}$ forest products become so scarce by the 1980 s that the problem not only attracted international attention, but Nepali farmers also began to develop their own methods for resolving this problem through community management?

The view that the Himalaya face a supercrisis has been labeled by Ives and Messerli (1989) as the Theory of Himalayan Environmental Degradation. They suggest that cries of massive recent deforestation in the Himalaya are not supported by evidence; that many arguments about 


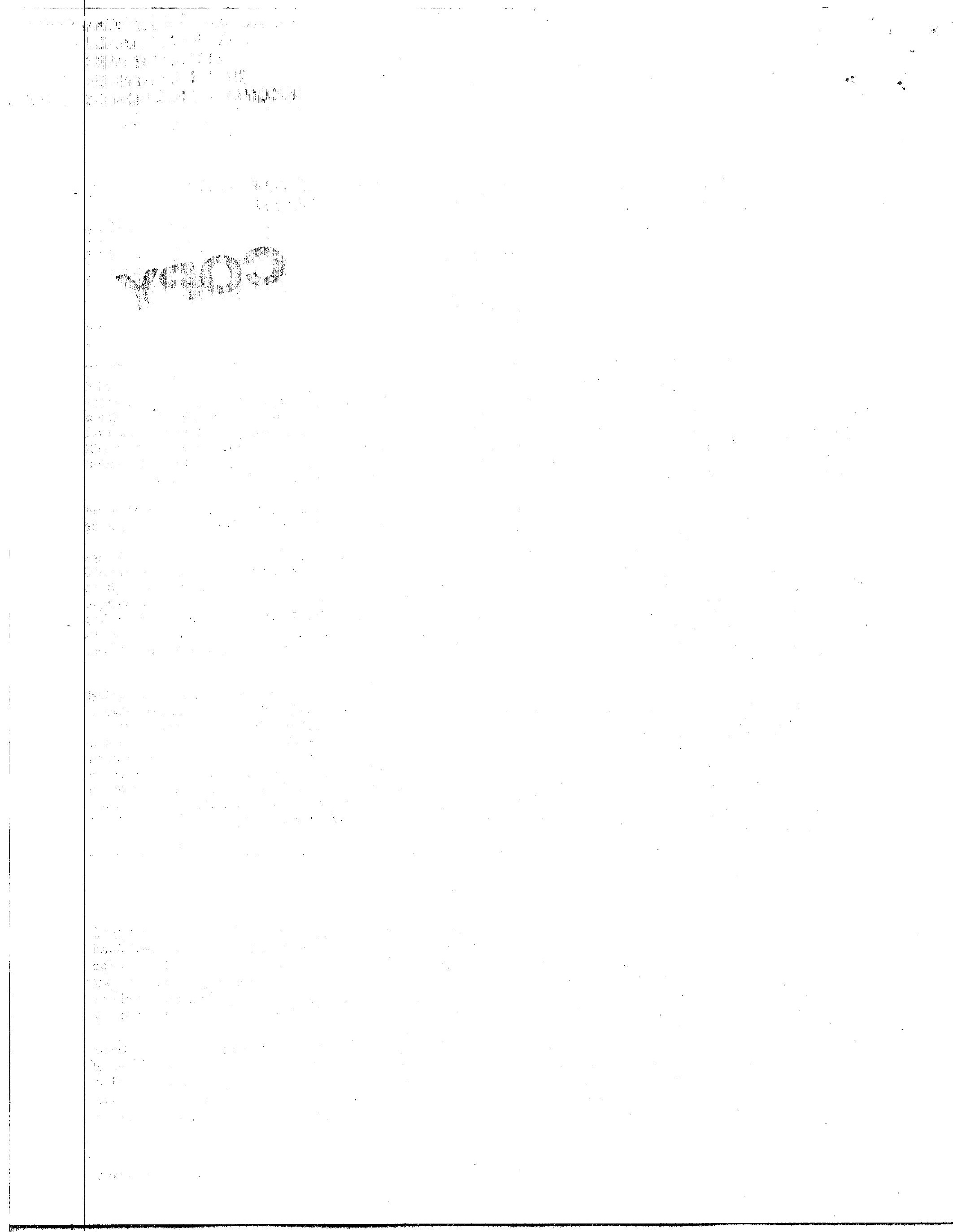



THE POSITIVE INFLUENCE OF POPULATION GROWTH

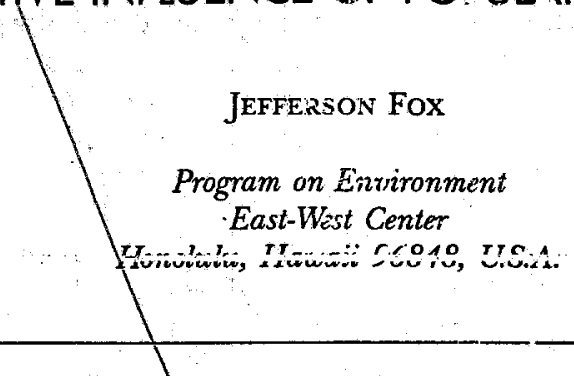

ABSTRACT This paper describes changes in forest condition and forest management practices in a Nepali village betwe and 1990, and attempts to identify the factors behind these changes. In 1980-81 the author spent a year studying forest-use pr and forest products in a village in the Middle Hills of central Nepal. Species composition, density (tree/ha), and tree size ( area) were described. The quantity of forest products collected from forest lands was measured. Weekly accounts were kept fi a sample of households on the amount of firewood and fodder collected, and the humber of hours animals were grazed. In 19 the author returned to the same village to resurvey forest lands and to assess changes in forest-use practices. Despite an annut population growth rate of $2.5 \%$, forests were found to be in much better condition in 1990 than they were in 1980 .

RÉSUMÉ Gestion des forèts dans un village népalais: l'influence positive de la cốzsance démographique. Cet article décrit les changements qui se sont produits entre 1980 et 1990 dans un village népalass, du pøint de vue de la condition des forêts et des pratiques de gestion de celles-ci, et essaie d'identifier les factors qui ont contribué a ces changements.

En 1980-81, l'auteur a passé une année à étudier les pratiques d’exploitation des forêts et les produits forestiers dans un village du Moyen Himalaya dans le Népal central. La distribution des espéces, la densité en nombre d'arbres par hectare et la taille des arbres (zone basale) sont décrites dans cet article. La production des terres forestières a été mesurée à l'aide de registres tenus pour un certain nombre de familles. Ces registres indiquent la quarlité de bois de chauffage et de fourrage récoltée chaque semaine, ainsi que le nombres d'heures pendant lesquelles lé bétail était au pâtuirage. En 1990, l'auteur est retourné dans le mếme village dans le but d'examiner de nouveau les terres forestières et d'évaluer les changements de pratiques d'exploitation des terres. En dépit d'une croissance démographique de 2,5 pour/cent par an, les forêts étaient en bien meilleure condition en 1990 qu'elles ne l'étaient en 1980 .

zUSAMMENFAsSUNG Waldmanagement in einem/nepalesischen Dorf: Der positive Einfluß des Bevölkenungswachstums. Dieser Artikel beschreibt Veränderungen in der Waldbeschaffénheit und im Waldmanagement eines nepalesischen Dorfes in den Jahren zwischen 1980 und 1990; und versucht, die den Veränderungen zugrunde liegenden Faktoren zu identifizieren. Der Autor verbrachte 1980/81 ein Jahr in einem Dorf der Middle Hills in Zentralnepal, um Methoden der Waldnutzung und die Waldprodukte zu untersuchen. Die Artenzusammensetzung, Dichte (Bäume/ha) und der Baumumfang (an der Basis) werden beskhrieben. Außerdem wurden die Waldprodukte, die auf den bewaldeten Flächen gesammelt wurden, quantitativ erfaßt. Ausgewählte Haushaltungen legten wöchentlich Rechenschaft darüber ab, wieviel Feuerholz und Viehfutter gesammelt wurden und wie lange das Vieh weidete. Im Jahre 1990 kehrte der Autor in Casselbe Dorf zurück, um die Waldflächen neu zu inspizieren und Verầnderungen in der Waldnutzung zu beurteilen. Trotz einer jährlichen Bevölkerungswachstumsrate von $2,5 \%$, fand er die Waldgebiete 1990 in besserem Zustand als im Jahre 1980.

\section{INTRODUCTION}

Since the early 1970s numerous authors have written about deforestation in Nepal as a result of uncontrolled use of forest lands by a rapidly growing rural population (Eckholm, 1976; Bishop, 1978; Hoffpauir, 1978). More recently other authors have begun to document examples of successful conservation and forest management efforts (see Messerschmidt, 1990; Stone, 1990; Fisher, 1991; Gilmour, 1991). What happened? Were the reports in the 1970s and early 1980s erroneous, or did they fail to predict how Nepali farmers would react to forest degradation and to shortages of forest products? Gilmour (1989) argues that there is an increased likelihood of indigenous forest management systems developing where forest products are relatively inaccessible. Is this the answer? $\mathrm{Had}$ forest products become so scarce by the 1980 s that the problem not only attracted international attention, but Nepali farmers also began to develop their own methods for resolving this problem through community management?

The view that the Himalaya face a supercrisis has been labeled by Ives and Messerli (1989) as the Theory of Himalayan Environmental Degradation. They suggest that cries of massive recent deforestation in the Himalaya are not supported by evidence; that many arguments about 
the role of forest in hydrology and soil erosion are based on myths and misunderstandings; and that there is no evidence deforestation in the hills leads to any significant increased flooding on the Ganges and Brahmaputra plains. Ives and Messerli conclude that the geophysical features of the Himalaya lead to an intrinsically unstable landscape against which attempts to measure the proportional impacts of human intervention are impossible. At the macro or regional scale, these geophysical rea tures (including the continuing process of uplift) reduce the role of human interventions to insignificant proportions.

While Tues and Messerli do an eloguent job of examining the physical "facts and pseudofacts of progressive reductions in forest cover and the assumed and real consequences of that reduction in terms of landscape degradation and far-distant downstream effects (IVes and Messerli, 1989:145), the human dimension of land-use change in the Himalayas remains poorly understood" (Fisher, 1990) No theory has been advanced that explains how variables such as population growth, development and its accompanying infrastructure, changes in land: tenure and other social institutions, or belief systems affect land use. The development of such a theory depends on documenting changes in forest and agricultural land-use practices and understanding the antecedent conditions that led to these changes!

Brookfield (1984) made a conceptual breakthrough in the development of a social theory of agrarian change
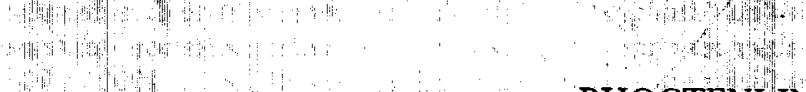

BHOGTENI IN

\section{Population and LaNd Resources}

Bhogteni is situated on the eastern ridge of the Daraundi watershed at about $1,200 \mathrm{~m}$. This elevation is a subtropical haven between the hot sultry climate of the river valley and the bitter cold winters farther up slope. It takes about an hour to walk northwards to the village, from Gorkha, the administrative center of the district.

The 1981 population of the village was 653 living in 107 households with an average household size of 6.1 people. By 1990 the population had grown to 835 living in 144 households of 5.8 people. The per year growth rate of the village is $2.46 \%$, compared with a national rate of $2.62 \%$ (Chhetri, pers. comm.). The number of households grew at a rate of $2.97 \%$ per year; this is faster than the population growth rate and suggests that family groups were breaking off to form new households.

In $1980,62 \%$ of the population were Brahmin-Chhetri, $18 \%$ were Newari, $16 \%$ belonged to service castes (Kami, Damai, and Sarkai), and $4 \%$ belonged to either Jogi or Magar caste groups. In 1990 these figures were $63 \%$, $17 \%, 10 \%$, and $10 \%$, respectively.

Villagers in Bhogteni own approximately 113 ha of agricultural land, and have access to 73 ha of SchimaCastanopsis scrub land and 39 ha of sal forest. In relation to land resources, the population density in 1981 was $290 / \mathrm{km}^{2}$, or in terms of cultivated lands and forest/ by defining two terms-innovation and intensification. Innovation is new practices or new combinations of practices that change the productivity or quality of a unit of labor input. Anything that introduces qualitative changes to the production system is an innovation (i.e., a change in land tenure is an innovation, and so is a change in the pattern of settiement). Intensification implies the process of applying greater amounts of labor inputs and other in puts within a particular technological and socioeconomic system. A social theory of agrarian change seeks to identify the opportunities as well as the pressures that trigger innovation.

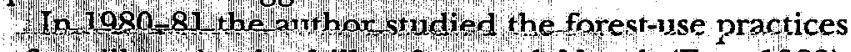
of a Nillage in the hills of central Nepal (Fox, 1983). Results indicated that the forests of this village were in poor condition and that the major causes of this degradation were the grazung and fodder collection required by the large livesto ck population. This finding contradicted the popular wisdon that "firewood collection" was the major cause of forest degradation In 1990 the author returned to this yllage to resurvey forest conditions and forestuse practices. In 1990 the forests of this village were in nuch better condition than they had been in 1980 . This paper documents the differences in forest conditions and forest products and seeks to determine if these changes are due to innovation on intensification and, if the changes are due to nnovation, what factors triggered these chang es Hit tit 14 1980 AND 1990

scrub/grazing lands, 577 and $583 / \mathrm{km}^{2}$. In 1990 these figures were 371,738 , and 745 persons $/ \mathrm{km}^{2}$, respectively. The average farm size in 1980 was estimated to be 1.1 ha, in 1990 the average farm had shrunk to 0.8 ha.

\section{LiYestock}

In 1980 the total livestock population of the village included 167 buffalo, 275 cattle, 303 goats, and 10 pigs.

TABLE 1

Livestock population

\begin{tabular}{lccccc}
\hline & \multicolumn{2}{c}{1980} & & \multicolumn{2}{c}{1990} \\
\cline { 2 - 5 } \cline { 4 - 5 } Livestock & Population & $\begin{array}{c}\text { Livestock } \\
\text { unit }\end{array}$ & & Population & $\begin{array}{c}\text { Livestock } \\
\text { unit }\end{array}$ \\
\hline Buffalo & 167 & 167 & & 195 & 195 \\
Cattle & 275 & 193 & & 242 & 169 \\
Goats & 303 & 30 & & 337 & 34 \\
Pigs & 10 & - & & 27 & - \\
Total & 755 & 390 & & 801 & 398 \\
\hline
\end{tabular}

Grazing livestock (cattle and goats): 223 (1980), 203 (1990)

Grazing capacity on public lands (approximately $154 \mathrm{ha}$ ): 48 to 128 livestock units. 

TABLE 3A

Mean number of animats per household per snoll medium and lang fams

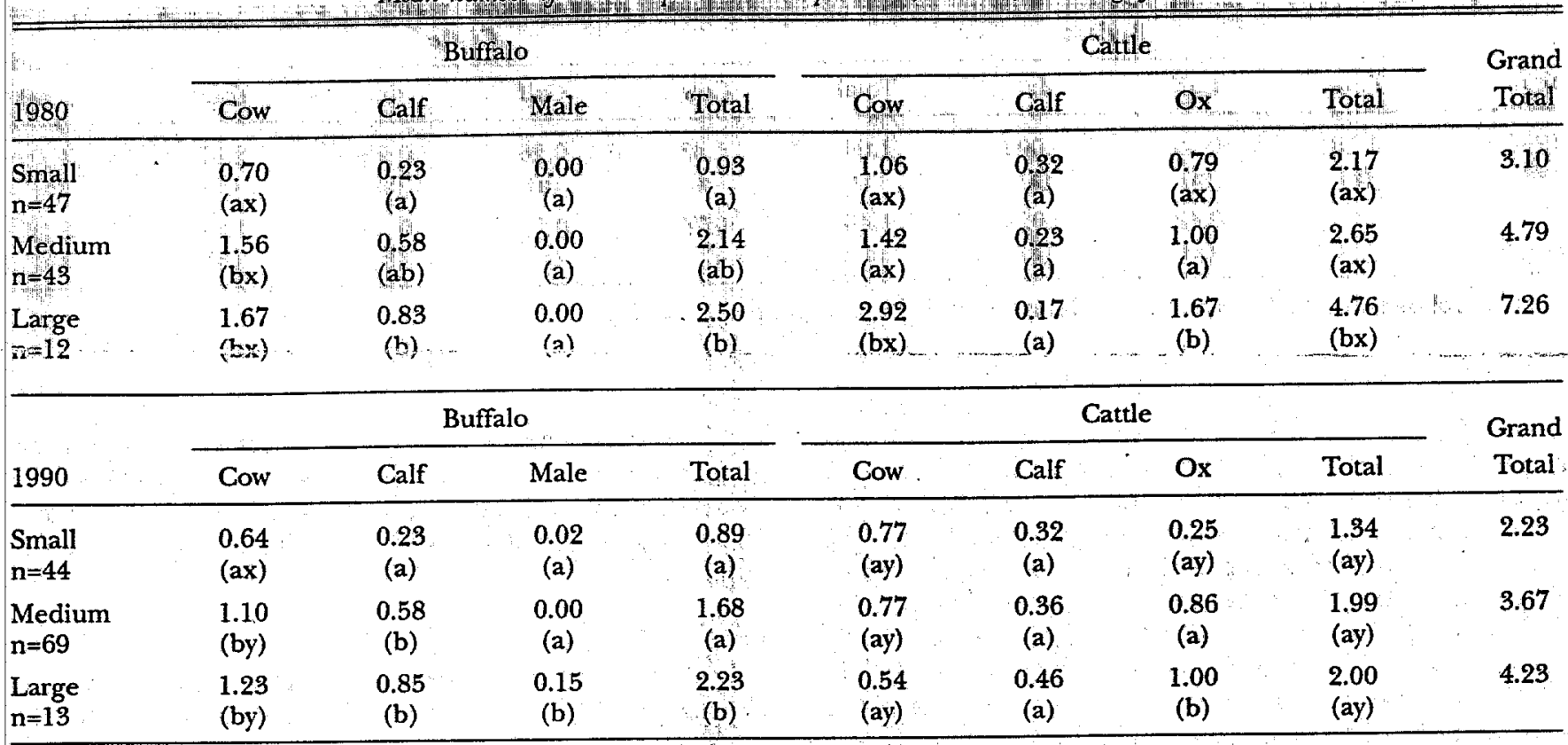

A mean followed by (a) is significantly different $(p<0.05)$ from one marked (b), but is not significantly different from a mean marked (a), or (ab) for values within the same time frame (1.e., 1980 or 1990). A mean followed by an (x) is significantly different $(p<0.05)$ from one marked $(y)$ for comparisons between 1980 and 1990 data.

TABLE 3B

Mean number of animals per household per caste group

\begin{tabular}{|c|c|c|c|c|c|c|c|c|c|}
\hline \multirow{2}{*}{1980} & \multicolumn{4}{|c|}{ Buffalo } & \multicolumn{4}{|c|}{ Cattle } & \multirow{2}{*}{$\begin{array}{l}\text { Grand } \\
\text { Total }\end{array}$} \\
\hline & Cow & Calf & Male & Total & Cow & Calf & $\mathrm{Ox}$ & Total & \\
\hline $\begin{array}{l}\text { Brahmin } \\
n=31\end{array}$ & $\begin{array}{l}1.48 \\
(\mathrm{ax})\end{array}$ & $\begin{array}{l}0.52 \\
\text { (a) }\end{array}$ & $\begin{array}{c}0.00 \\
\text { (a) }\end{array}$ & $\begin{array}{l}2.00 \\
\text { (a) }\end{array}$ & $\begin{array}{l}2.39 \\
(\mathrm{ax})\end{array}$ & $\begin{array}{l}0.23 \\
\text { (a) }\end{array}$ & $\begin{array}{l}1.06 \\
\text { (a) }\end{array}$ & $\begin{array}{l}3.68 \\
(\mathrm{ax})\end{array}$ & 5.68 \\
\hline $\begin{array}{l}\text { Chhetri } \\
n=35\end{array}$ & $\begin{array}{l}1.49 \\
(\mathrm{ax})\end{array}$ & $\begin{array}{c}0.57 \\
\text { (a) }\end{array}$ & $\begin{array}{c}0.00 \\
\text { (a) }\end{array}$ & $\begin{array}{l}2.06 \\
\text { (a) }\end{array}$ & $\begin{array}{l}1.14 \\
(\mathrm{bx})\end{array}$ & $\begin{array}{l}0.34 \\
\text { (a) }\end{array}$ & $\begin{array}{l}1.06 \\
\text { (a) }\end{array}$ & $\begin{array}{c}2.54 \\
(a b x)\end{array}$ & 4.60 \\
\hline $\begin{array}{l}\text { Newar } \\
n=19\end{array}$ & $\begin{array}{l}0.68 \\
\text { (b) }\end{array}$ & $\begin{array}{c}0.47 \\
\text { (a) }\end{array}$ & $\begin{array}{c}0.05 \\
\text { (a) }\end{array}$ & $\begin{array}{l}1.20 \\
\text { (b) }\end{array}$ & $\frac{1.16}{(a b x)}$ & $\begin{array}{l}0.26 \\
(a)\end{array}$ & $\begin{array}{l}1.05 \\
(a)\end{array}$ & $\begin{array}{l}2.47 \\
(a b)\end{array}$ & 3.67 \\
\hline \multirow[t]{2}{*}{$\begin{array}{l}\text { Service } \\
\mathrm{n}=17\end{array}$} & $\begin{array}{c}0.53 \\
\text { (b) }\end{array}$ & $\begin{array}{c}0.06 \\
\text { (b) }\end{array}$ & $\begin{array}{c}0.00 \\
\text { (a) }\end{array}$ & $\begin{array}{l}0.59 \\
\text { (b) }\end{array}$ & $\begin{array}{l}0.59 \\
\text { (c) }\end{array}$ & $\begin{array}{c}0.18 \\
\text { (a) }\end{array}$ & $\begin{array}{c}0.59 \\
\text { (a) }\end{array}$ & $\begin{array}{l}1.36 \\
(\mathrm{bx})\end{array}$ & 1.95 \\
\hline & \multicolumn{4}{|c|}{ Buffalo } & \multicolumn{4}{|c|}{ Cattle } & Grand \\
\hline 1990 & Cow & Calf & Male & Total & Cow & Calf & $\mathrm{Ox}$ & Total & Total \\
\hline $\begin{array}{l}\text { Brahmin } \\
\mathrm{n}=37\end{array}$ & $\begin{array}{l}1.16 \\
\text { (ay) }\end{array}$ & $\begin{array}{c}0.54 \\
\text { (a) }\end{array}$ & $\begin{array}{c}0.03 \\
(\mathrm{a})\end{array}$ & $\begin{array}{r}1.73 \\
\text { (a) }\end{array}$ & $\begin{array}{l}0.95 \\
\text { (ay) }\end{array}$ & $\begin{array}{l}0.46 \\
\text { (a) }\end{array}$ & $\begin{array}{l}0.65 \\
\text { (a) }\end{array}$ & $\begin{array}{l}2.06 \\
\text { (ay) }\end{array}$ & 3.79 \\
\hline $\begin{array}{l}\text { Chhetri } \\
n=50\end{array}$ & $\begin{array}{l}1.00 \\
\text { (ay) }\end{array}$ & $\begin{array}{c}0.50 \\
(\mathrm{a})\end{array}$ & $\begin{array}{c}0.02 \\
(a)\end{array}$ & $\begin{array}{l}1.52 \\
\text { (a) }\end{array}$ & $\begin{array}{l}0.80 \\
\text { (ay) }\end{array}$ & $\begin{array}{l}0.38 \\
\text { (a) }\end{array}$ & $\begin{array}{l}0.88 \\
\text { (a) }\end{array}$ & $\begin{array}{l}2.06 \\
\text { (ay) }\end{array}$ & 3.58 \\
\hline $\begin{array}{l}\text { Newar } \\
n=25\end{array}$ & $\begin{array}{l}0.84 \\
(\mathrm{ab})\end{array}$ & $\begin{array}{c}0.48 \\
\text { (a) }\end{array}$ & $\begin{array}{c}0.04 \\
\text { (a) }\end{array}$ & $\begin{array}{l}1.36 \\
\text { (a) }\end{array}$ & $\begin{array}{l}0.56 \\
\text { (ay) }\end{array}$ & $\begin{array}{l}0.32 \\
(a)\end{array}$ & $\begin{array}{c}0.60 \\
\text { (a) }\end{array}$ & $\begin{array}{c}1.48 \\
\text { (aby) }\end{array}$ & 2.84 \\
\hline $\begin{array}{l}\text { Service } \\
n=14\end{array}$ & $\begin{array}{l}0.43 \\
\text { (b) }\end{array}$ & $\begin{array}{c}0.29 \\
\text { (a) }\end{array}$ & $\begin{array}{c}0.00 \\
(\mathrm{a})\end{array}$ & $\begin{array}{l}0.72 \\
\text { (b) }\end{array}$ & $\begin{array}{l}0.36 \\
\text { (a) }\end{array}$ & $\begin{array}{l}0.07 \\
\text { (a) }\end{array}$ & $\begin{array}{c}0.00 \\
\text { (b) }\end{array}$ & $\begin{array}{l}0.43 \\
\text { (by) }\end{array}$ & 1.15 \\
\hline
\end{tabular}

A mean followed by (a) is significantly different $(\mathrm{p}<0.05$ ) from one marked (b) or (c), but is not significantly different from a mean marked (a), or (ab) for values within the same time frame (i.e., 1980 or 1990). A mean followed by an (x) is significantly different $(p<0.05)$ from one marked $(y)$ for comparisons between 1980 and 1990 data. 
TABle 4A

Wood volume estimates: $1980-81$

\begin{tabular}{|c|c|c|c|c|c|c|}
\hline $\mathrm{DBH}$ & Timber & $\begin{array}{l}\text { Small trees } \\
\text { and tops }\end{array}$ & Branches & Total & Area & Total \\
\hline $\mathrm{cm}$ & $\mathrm{m}^{3} / \mathrm{ha}$ & $\mathrm{m}^{3} / \mathrm{ha}$ & $\mathrm{m}^{3} / \mathrm{ha}$ & $\mathrm{m}^{3} / \mathrm{ha}$ & ha & $\mathrm{m}^{3}$ \\
\hline \multicolumn{7}{|l|}{ Private } \\
\hline$<13$ & - & 0.28 & 0.28 & 0.56 & 42 & 24 \\
\hline $13-30$ & 23 & 3.00 & 6.00 & 32.00 & 42 & 1,344 \\
\hline$>\mathbf{3 0}$ & 37 & 1.00 & 4.00 & 42.00 & 42 & 1,764 \\
\hline Total & $60 \ldots$ & 4.28 & 10.28 & 74.56 & 42 & 3,132 \\
\hline \multicolumn{7}{|l|}{ Communal } \\
\hline$<13$ & - & 0.04 & 0.04 & 0.08 & 73 & 6 \\
\hline $13-30$ & 3 & 0.40 & 0.85 & 4.25 & 73 & 310 \\
\hline$>30$ & 4 & 0.10 & 0.45 & 4.55 & 73 & 332 \\
\hline Total & 7 & 0.54 & 1.34 & 8.88 & 73 & 648 \\
\hline \multicolumn{7}{|l|}{ Government } \\
\hline$<13$ & - & 4.74 & 4.74 & 9.48 & 39 & 370 \\
\hline $13-30$ & 36 & 9.00 & 11.25 & 56.25 & 39 & 2,194 \\
\hline$>30$ & 35 & 1.24 & 4.00 & 40.26 & 39 & 1,570 \\
\hline Total & 71 & 14.98 & 19.99 & 105.99 & 39 & $\therefore 4,134$ \\
\hline Grand total & & & & & & 7,914 \\
\hline
\end{tabular}

TABLE 4B

Wood volume estimates: 1990

\begin{tabular}{|c|c|c|c|c|c|c|}
\hline $\mathrm{DBH}$ & Timber & $\begin{array}{l}\text { Small trees } \\
\text { and tops }\end{array}$ & Branches & Total & Area & Total \\
\hline $\mathrm{cm}$ & $\mathrm{m}^{3} / \mathrm{ha}$ & $\mathrm{m}^{3} / \mathrm{ha}$ & $\mathrm{m}^{3} / \mathrm{ha}$ & $\mathrm{m}^{3} / \mathrm{ha}$ & ha & $\mathrm{m}^{3}$ \\
\hline \multicolumn{7}{|l|}{ Private } \\
\hline$<13$ & - & 0.28 & 0.28 & 0.56 & 42 & $\quad 24$ \\
\hline $13-30$ & 28 & 3.95 & 7.91 & 39.86 & 42 & 1,660 \\
\hline$>30$. & 14 & 0.51 & 1.60 & 16.11 & 42 & 674 \\
\hline Total & 42 & 4.74 & 9.79 & 56.53 & 42 & 2,358 \\
\hline \multicolumn{7}{|l|}{ Communal } \\
\hline$<13$ & - & 7.07 & 7.07 & 14.14 & 73 & 1,032 \\
\hline $13-30$ & 12 & 1.53 & 3.44 & 16.97 & 73 & 1,257 \\
\hline$>30$ & 13 & 0.41 & 1.51 & 14.92 & 73 & 1,100 \\
\hline Total & 25 & 9.01 & 12.02 & 46.03 & 73 & 3,389 \\
\hline \multicolumn{7}{|l|}{ Government } \\
\hline$<13$ & - & 59.50 & 59.50 & 119.00 & 39 & 4,644 \\
\hline $13-30$ & 48 & 7.40 & 13.80 & 69.20 & 39 & 2,691 \\
\hline$>30$ & 0 & 0.00 & 0.00 & 0.00 & 39 & 0 \\
\hline Total & 48 & 66.90 & 73.30 & 188.20 & 39 & 7,335 \\
\hline Grand total & & & & & & 13,082 \\
\hline
\end{tabular}

These committees allowed people to collect firewood and leaves for roofing, and to graze livestock. Cutting large trees was prohibited. These committees operated informally and their activities were limited to forest protec- tion. Committees were formed to manage portions of the sal forest, as well as most of the Schima-Castanopsis remnants. 


\section{MUUNTAIN RESEARCH AND DEVELOPMENT \\ FOREST RESOURCES}

In 1980 private woodlots had 179 trees/ha, 92\% of which were Schima wallichtiand $8 \%$ miscellaneous spedies (primarily Castanopsis indica). In 1990 private woodlots had 489 trees/ha. Whereas in 1980 the basal area of an average tree was $562 \mathrm{~cm}^{2}$, by 1990 this figure had dropped to $200 \mathrm{~cm}^{2}$, Likewise, in 1980, communal forests had less than 26 trees/ha, primarily Schima wallichii, with an average basal area of $474 \mathrm{~cm}^{2}$ per tree. By 1990 these forests had an average of more than 450 trees/ha, and the size of the average tree had decreased to $139 \mathrm{~cm}^{2}$. In 1980 government-owned sal forests had 746 trees/ha,

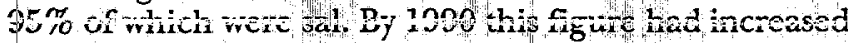
over fourfold to 3,345 trees/ha. The size of the average sal tree in 1980 was $232 \mathrm{~cm}^{2}$ per tree; by 1990 this figure was $63 \mathrm{~cm}^{2}$. The size of an average tree in 1990 decreased because the number of small trees increased tremendously. The total basal area (a product of the number of trees/ha and mean basal area $-\mathrm{m}^{2} / \mathrm{ha}$ ), however, was higher in 1990 than in 1980 because of the great increase in the number of trees per hectare.

Wood volume was estimated using tables compiled by the Department of Forestry (1973). Tables $4 A$ and $B$ show tree volume estimates for the three forest categories in 1980-81 and 1990. In 1980 timber volumes in Bhogteni ranged from $9 \mathrm{~m}^{3} /$ ha on communal lands to $106 \mathrm{~m}^{3} / \mathrm{ha}$ on government-owned lands; in 1990 these figures were $46 \mathrm{~m}^{3} /$ ha to $188 \mathrm{~m}^{3} / \mathrm{ha}$, respectively. Average mean annual increments (tree growth) on communal and government-owned lands increased tremendously in 1990 when compared to 1980-81 statistics (see Tables $5 \mathrm{~A}$ and B).

\section{DEMAND FOR Forest Products}

The 1980 study suggested that villagers used their local forests for grazing livestock and for collecting fodder and firewood. Because the total livestock population in 1990 is approximately the same as the 1980 population and the number of grazing livestock (cattle and goats) has actually decreased, the demand for leaf fodder from the forest and for grazing has remained constant or decreased during this period. Data were not collected in 1990 to make it possible to estimate the portion of fodder collected from the forest as opposed to private land:

Furthermore, the 1980 study indicated that tree fodder is collected from, and livestock are grazed on, public lands primarily at the end of the dry season, May and June (the 1990 research was conducted in December). This is a livestock feed-shortage period, a time that public lands serve as a critical source of tree fodder and a place for grazing livestock until grass fodder becomes available. Although in 1990 it was visually obvious that farmers have greatly increased (three-to-fourfold) the number of fodder trees grown on private land, it would be useful to quantify the value of public forests as sources of tree fodder and places to graze livestock during the dry season.

In 1980 firewood consumption rates were measured using three methods, and the relative influence of farm size, family size, caste, and season of the year on firewood
TÁBLE 5A

1. Wod volume mean annual increments: 1980-81

\begin{tabular}{|c|c|c|c|}
\hline $\mathrm{DBH}$ and & Volume & Growth rate & MAI \\
\hline $\mathbf{c m} \quad$ & $\mathrm{m}^{3} / \mathrm{ha}$ & $\mathrm{m}^{3} / \mathrm{m}^{3} / \mathrm{yr}$ & $\mathrm{m}^{3} / \mathrm{ha} /$ year \\
\hline \multicolumn{4}{|l|}{ Private } \\
\hline$<13$ & 0.56 & 0.07 & 0.04 \\
\hline $13-30$ & 32.00 & 0.05 & 1.60 \\
\hline$>30$ & 42.00 & 0.02 & 0.84 \\
\hline Total & 74.56 & - & 2.48 \\
\hline \multicolumn{4}{|l|}{ Communal } \\
\hline$<13$ & 0.08 & 0.07 & 0.06 \\
\hline $13-30$ & 4.25 & 0.05 & 0.21 \\
\hline$>\mathbf{3 0}$ & 4.55 & 0.02 & 0.09 \\
\hline Total & 8.88 & - & 0.36 \\
\hline \multicolumn{4}{|l|}{ Government } \\
\hline$<13$ & 9.48 & 0.07 & 0.66 \\
\hline $13-30$ & 56.25 & 0.05 & 2.81 \\
\hline$>30$ & 40.26 & 0.02 & 0.80 \\
\hline Total & 105.99 & - & 4.27 \\
\hline \multicolumn{3}{|c|}{ Average for all forests } & 1.93 \\
\hline
\end{tabular}

TABLE 5B

Wood volume mean annual increments: 1990

\begin{tabular}{lccc}
\hline DBH & Volume & Growth rate & MAI \\
\hline $\mathrm{cm}$ & $\mathrm{m}^{3} / \mathrm{ha}$ & $\mathrm{m}^{3} / \mathrm{m}^{3} / \mathrm{yr}$ & $\mathrm{m}^{3} / \mathrm{ha} /$ year \\
\hline Private & & & \\
$<13$ & 10.64 & 0.07 & 0.75 \\
$13-30$ & 39.86 & 0.05 & 1.99 \\
$>30$ & 16.10 & 10.02 & 0.32 \\
Total & 66.60 & - & 3.06 \\
\hline Communal & & & \\
$<13$ & 14.14 & 0.07 & 0.99 \\
$13-30$ & 16.97 & 0.05 & 0.85 \\
$>30$ & 14.92 & 0.02 & 0.30 \\
Total & 46.03 & $\mathbb{1 4}$ & 2.14 \\
\hline Government & & $\cdots$ & \\
$<13$ & 119.00 & 0.07 & 8.33 \\
$13-30$ & 69.20 & 0.05 & 3.46 \\
$>30$ & 0.00 & 0.02 & 0.00 \\
Total & 188.20 & - & 11.79 \\
\hline Average for all forests & & 4.76 \\
\hline
\end{tabular}

consumption rates was determined (Fox, 1984). In 1990 , rates were remeasured using two of the original three methods. 
TABLE 6

Finewood consumption ( $m^{3} /$ capita/year)

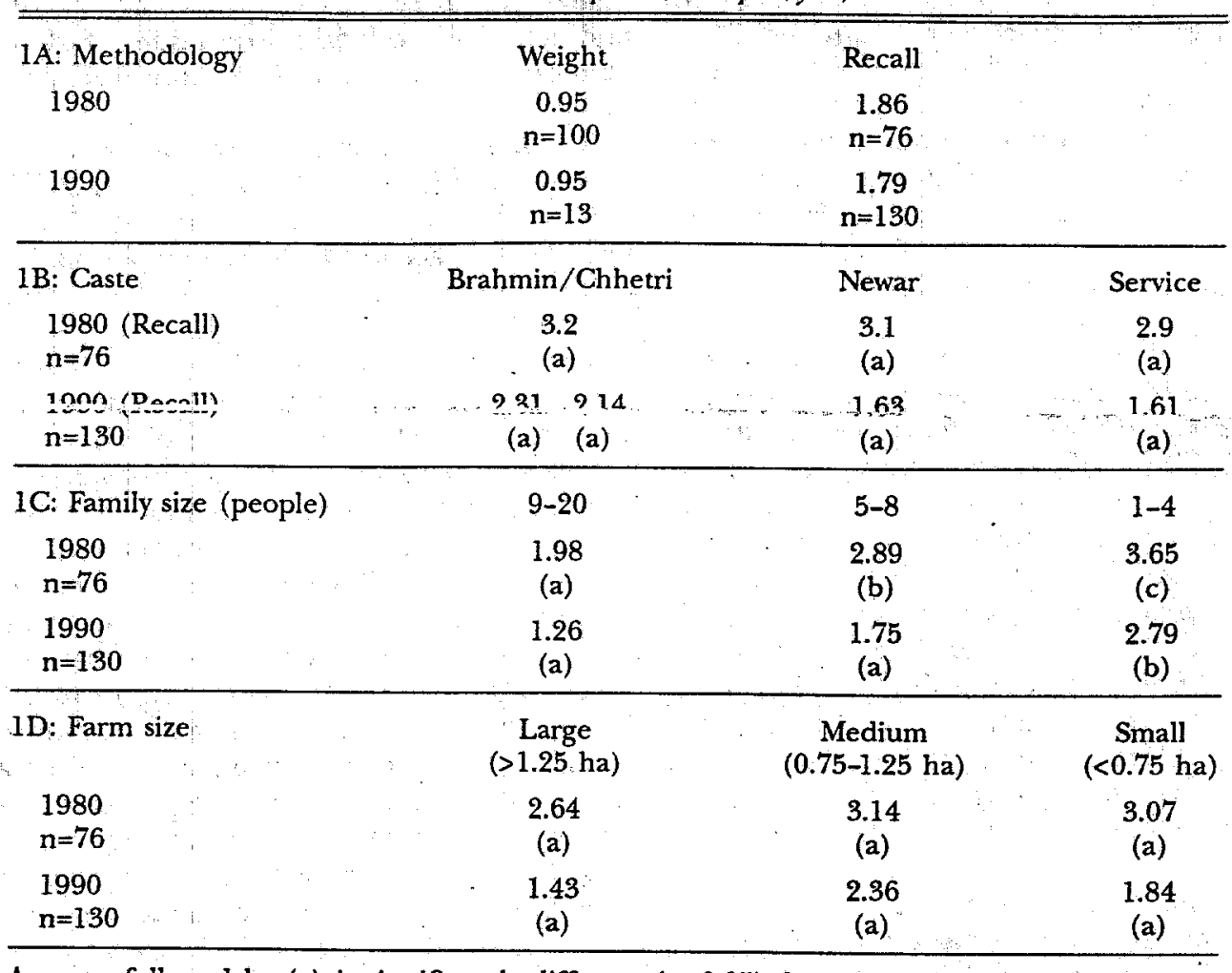

A mean followed by $(a)$ is significantly different $(p<0.05)$ from one marked $(b)$ or $(c)$, but is not significantly different from a mean marked (a).

For the weight study, firewood was weighed at each participating household. Firewood was weighed on four separate occasions in 1980 and on a single visit in December 1990 . In the recall survey, participants were asked two questions: (1) how much wood do you burn daily in the cold season? (2) how much wood do you burn daily in the warm season? In 1980 and 1990, 76 and 130 households participated in this survey, respectively. Table 6 shows firewood consumption rates according to year and methodology. No significant differences were observed between average firewood consumption rates in 1980 and 1990.

When the survey results are broken down by caste and farm size, no significant differences were observed in 1980 or in 1990 . When broken down by family size, however, significant differences occurred within each group in both time periods (i.e., large families burn less wood per person than small families). These results indicate that firewood demand patterns have remained constant throughout the 10year period. ${ }^{1}$

As for supply, the annual increment of wood available for fuel is the sum of wood growth and deadwood generation For example, using $3 \%$ of total wood as an estimate of annual deadwood generation, the estimated annual firewood supply from all sources (private, common, and government forests) in 1980 was approximately $370,000 \mathrm{~kg}$ year. By 1990 firewood supply had grown to approximately $800,000 \mathrm{~kg}$ /year. Firewood demand, how- ever, has only grown from 350,000 to $478,000 \mathrm{~kg}$ /year; thus firewood supplies are currently sufficient to meet demand.

\section{Chronology of Change}

Between 1980 and 1990 a number of events occurred that affected forest resources in the village. The following is a brief chronology of these changes:

In 1976 the panchayat-protected forest and panchayatforest regulations were passed. Although this occurred before the 1980-81 study began, it was during this decade that the community began to act on the basis of these regulations.

In 1981 and 1982 the Resource Conservation and Utilization Project (RCUP), funded by USAID, conducted enrichment plantings on several pieces of forest lands. RCUP hired villagers for a 4year period to protect these plantations. During this time, grazing and collecting of firewood and fodder were prohibited, but villagers were

\footnotetext{
${ }^{1}$ Thompson and Warburton (1985) cite Donovan's (1981) review of firewood consumption rates (varying by a factor of 67) as proof of the magnitude of the uncertainties faced in the Himalaya. My study of firewood consumption (Fox, 1984) is not cited. Clearly, however if firewood consumption rates can be replicated at a 10-year interval and show no significant differences, we can conclude that we know something about how to document firewood consumption and about total consumption rates. The Himalaya may face great uncertainty, but firewood consumption rates are not a good example.
}

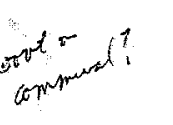




\section{6 \% Mountain Research AND DeVELoPMENT}

allowed to collect dry firewood. Once the forests were protected from grazing, native species quickly regenerated and shaded out the enrichment plantings. The closure of the village's forest land to grazing livestock forced villagers to stall feed their animals and may have led to the change in total livestock composition (more buffalo and fewer cattle). Farmers also increased the number of fodder trees they grew on their private lands.

In 1982 the road from Gorkha to Kathmandu and Pokhara was completed. This allowed villagers to import chemical fertilizers and thus maintain or increase per capita agricultural production without a simultaneous increase in the alternative source of nutrients, manure.

In 1985 the RCUP guards were removed and the protected forest lands turned over to the Department of Forestry. The department lacked the resources to manage these small pieces of forest and turned them over to the panchayat for management. This was an informal arrangement and neither the Department of Forestry nor the panchayat made any effort to complete the formal paperwork necessary to officially record this land as panchayat or panchayat-protected forest. Patches of forest land near poorer households were quickly degraded again; those near more wealthier households were protected by the local community.

By 1990 villagers had established forest protection committees to protect seven individual pieces of forest lands. These formal committees have a chairperson, secretary, and designated household members who reside around the piece of forest land. Rules governing the managernent of these pieces of forest vary by committees. Sonne committees allow grazing and the cutting of grass and dead firewood; other committees forbid grazing. The committees have the right to fine offenders but seldom do so."t

In 1990 the committee for the sal forest hired local farmers to thin the regenerated sal forest. Two factors lay behind the committee's decision to thin the forest-a management activity First, a small population of leopards had returned to the regenerated sal forest and were perceived as a threat to children walking to school. The protection committee felt it essential to cut the vegetation near the trail for the safety of the children. Second, the panchayat system of government was overthrown by a people's movement. With its removal, the protection committee no longer had to share the income of the management activity with the panchayat leader.

In December 1990 the sal forest committee was embroiled in a controversy over how to divide the products of the forest-thinning activity. Villagers were involved in heated arguments over who had rights to this wood (i.e., defining who is in and who is not in the forest protection committee). In general, any member of the ward in which the forest is located has a right to forest products. Although the committees are heterogeneous and reflect the make-up of the population of the user group, people from the service castes are inadequately represented. These committees are still developing. With proper leadership and guidance they could become influential, stabilizing forces in the community.

\section{TOWARD A THEORY OF AGRARIAN CHANGE}

Malthus argues that society faced with rising population will reach the limits of its ability to produce more food, and will enter a downward spiral of land degradation and starvation. Today, neo-Malthusians continue to portray the world as a place where growing populations are pressing against a food potential, which not only is incapable of increase but is even gradually being reduced by the action of these growing populations. Many researchers regard increasing populations as a major cause of tropical forest decline (e.g., Allen and Barnes, 1985; Grainger, 1986; Panayotou and Sungsuwan, 1989).

Other authors such as Wittfogel (1957), Boserup (1965), and Geertz (1966) have suggested different ways in which the closer occupation of agricultural land might come about. Boserup's recognition that innovation could arise from within society was the major contribution of this period. Contrary to Malthus, Boserup argues tha population growth is the major cause of positive change.

Brookfield (1984) suggests that it is essential to differentiate between innovation and intensification. He then argues that Boserup was wrong to focus on population as the only major cause of innovation (Brookfield, 1984:39). He suggests that reduction of risk, "especially but not only the rising risk of deteriorating environment under pressure," is a major reason for innovation adoption. He notes, however, that it is necessary to have a surplus to risk in order to reduce risk: "An external source such as a new high-yielding crop may provide the necessary surplus, while social innovations arising from supra-local integration may also provide the opportunity to divert resources to investment" (Brookfield, 1984: 39).

The continuing rapid population growth rate in Bhogteni and the already high population density may have contributed to the willingness of villagers to seek more efficient methods of managing forest lands. But clearly other variables were at work as well.

Perhaps the most significant factor affecting change in Bhogteni was the introduction of new tenure regime for forest lands (through the recognition of panchayat forest and panchayat-protected forest in 1976). This change, emanating from the efforts of the World Bank and the international donor agencies which perceived a high risk of environmental degradation, led to a new innovationcommunity groups assuming responsibility for managing forest lands. Once villagers realized that protection committees are sanctioned by government officials, they quickly developed their own methods for managing local resources. The new tenure regime provided incentives for 
local people to divert resources to the management of forest lands. The fall of the panchayat system and the establishment of a more democratic government have also encouraged farmers to invest labor into managing forest lands through community programs. These changes have clearly led to a more efficient management system that increases the productivity or quality of a unit of labor input.

Another major change in Bhogteni was the introduction of the road. This allowed villagers to import chemical fertilizers and thus maintain or increase per capita agricultural production without a simultaneous increase in livestock numbers. Although the changes induced by the road have increased the intensity with which agricultural lands are used, these changes have also reduced the work load of farmers (fewer livestock/capita means less labor). Farmers have invested this surplus of labor in higher value livestock (buffalo) which they stall feed. This has resulted in a more efficient forest management system. In addition, the road has encouraged village youths to migrate to Kathmandu and to the Terai (tarai) for education and seasonal job opportunities.

A third major change in Bhogteni has been the role of outsiders (the Resource Conservation and Utilization Project [RCUP] and the non-government organizations) in helping villagers adjust to environmental change. The effect of these efforts is less clear. When the RCUP closed forests to grazing, villagers were forced to stall feed their livestock and to grow more fodder on their private lands. This effort, however, would not have been successful without the change in forest tenure policies (to encourage farmers to assume responsibility for forest management) and the construction of the new road. Together with these other changes, however, outsiders provided another surplus (e.g., job opportunities in the nursery, free seedlings) that villagers invested in adopting a more sustainable forest management system.

Other agents of change that may play a larger role in Bhogteni in the future are small non-government organizations. Within the last several years, a women's development project and the Save-the-Children organization have started working in Bhogteni and are supporting community forestry efforts. Ironically, however, both organizations are also encouraging livestock-raising projects.

In Bhogteni the human dimensions of land-use change are more complex than might be suggested by theory. During this 10-year period the village has undergone both intensification, increased production on agricultural lands as a result of the application of fertilizers, and innovation, improved management of forest lands as a result of new forest policies. The new road was a factor in both the intensification and innovation processes and it is not clear that either change could have occurred without it. In addition, perceived environmental risk was an important factor in the design and adoption of new forest policies.

This was true both in terms of external actors such as the World Bank and other donor agencies who pushed for the adoption of the new laws, and internal actors, the farmers who invested in organizing community management of forest lands. The role of population growth in this process is less obvious. While clearly neo-Malthusians were wrong-population growth did not lead to further land degradation - there is no evidence to confirm Boserup's (1965) hypothesis that population growth would lead to internal innovations for managing forest lands more efficiently. Forests, however, would not have been perceived as being at risk by either external or internal actors if it were not for the high population density and growth rate.

It is important to remember that this is a village study and that these results cannot be generalized to the rest of Nepal. But when these results are considered along with Gilmour's (1991) work in the Jhiku Khola watershed, the evidence begins to indicate that, despite continued population growth, more sustainable forest management systems are being established throughout the hills. The Malthusian theory of population growth and resource degradation is clearly a myth that needs to be slain before the human dimensions of environmental degradation in the Himalaya can be understood.

Although the changes discussed are encouraging, the question remains, how sustainable are they? Rather than answer this question, I would like to pose three more questions. The answers to these questions may determine the future of forest-use practices in Bhogteni.

1. How stable are the forest management committees? To the extent these committees represent an outsider's view of how villagers should manage their forest resources, these committees will probably fail. Villagers will need to decide (implicitly or explicitly) the nature of the social arrangement, the nature of the harvesting practices and controls to be applied, and who will be included as members of the user community.

2. What will be the direction of the government's forest management program? To the extent to which the government supports user committees, they may be able to exert a positive influence on forest-use practices. These committees are badly in need of information on productive methods of managing regenerated forests. The government could play a positive role in conducting research on this question and providing forest extension services to user committees.

3. How stable is the "new" agrosystem with its increased use of chemical fertilizers? Is the use of chemical fertilizers sustainable in the Nepali context? If the answer to this question is no, farmers may soon be raising more livestock than the forest can sustain.

In terms of the broader question of population and deforestation these results are simultaneously encouraging as well as disturbing. It is encouraging that population growth does not necessarily lead to a downward spiral of land degradation and starvation. Brookfield's (1984) theory that innovations that support more sustainable management systems can be triggered by a number of factors, including population growth and perceived envi- 


\section{8 / Mountain Research aNd Development}

ronmental risk, appears to be correct. In this case, changes in forest tenure, in troduction of a new road, and forest management inputs from outside sources have led to a new forest management paradigm. The new community forest management groups provide a more efficient management system in which the productivity or quality of a unit of labor has been increased.

The disturbing aspect of these results is the suggestion that forest degradation must be fairly severe before perceived environmental risk causes forest management policies to be changed. Once forests are degraded and few products of commercial value remain, it is less

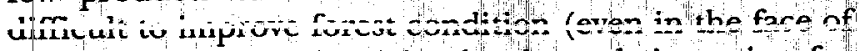
population growth) by giving local people incentives for managing local forests. It is much more difficult to protect valuable forest lands in sparsely populated, undegraded environments such as Indonesian Kalimantan or the Amazon. We should recognize, however, that the immediate threat to these lands is not population growth but bad forest management policies. Before population

\section{REFERENCES}

Allan, N. J. R., 1986: Accessibility and altitudinal zonation models of mountains. Mountain Research and Development, 6(3): 183-194.

Allen, J. C., and Barnes, D. F., 1985: The causes of deforestation in developing countries. Annals of the Association of American Geographers, 75: 163-184.

Bishop, B., 1978: The changing geoecology of the Karnali Zone, western Nepal: A case of stress. Artic and Alpine Research, 10: 531-548.

Boserup, E., 1965: The Conditions of Agricultural Growth: The Economics of Agrarian Change Under Population Pressure. Allen and Unwin, London.

Brookfield, H.C., 1984: Intensification revisited: Pacific Viezopoint, 25(1): 15-44.

Department of Forestry, 1973: Forest Resources Survey. Forest statistics for the hill region. Kathmandu.

Donovan, D. G., 1981: Firewood: How much do we need? Institute of Current World Affairs, Hanover, New Hampshire.

Eckholm, E. P., 1976: Losing Ground: Environmental Stress and World Food Prospects. W. W. Norton, New York.

Fisher, R. J., 1990: The Himalayan dilemma: Finding the human face. Pacific Viewpoint, 31(1): 69-71.

1991: Studying indigenous forest management systems in Nepal: Towards a more systematic approach. Working Paper No. 30, Environment and Policy Institute, East-West Center, Honolulu.

Fox, J. M., 1983: Managing public lands in a subsistence economy: The perspective from a Nepali village. Ph.D. dissertation, University of Wisconsin, Madison. , 1984: Firewood consumption in a Nepali village. Environmental Management, 8(3): 243-250. 1987: Livestock ownership patterns in a Nepali village. Mountain Research and Development, 7(2): 169-172.

Geertz, C., 1966: Agricultural Involution: The Process of Ecological Change in Indonesia. University of California Press, Berkeley and Los Angeles. can be cited as the cause of forest degradation, forest policies must be implemented that provide incentives (rather then disincentives) for local people to manage forest resources. tint resoly

\section{ACKNOWLEDGEMENTS}

I would like to acknowledge the many people who assisted me in conducting this research and writing this paper. In the field the assistance of Buddhi Rijal, Davesh Mani Tripathi, Ganesh Bahadur Karki, Jagannath Joshi, Krishna Prashad Arharva. Naravan Prashad Sharma, Shir Prashad Sharma, and Surya Kant Siqdel was invaluable. Drs. Ram Chhetri and Neeranjan Rajbhandari assisted with the preparation of the questionnaire, and data coding and analysis. Comments from Dr. Jack Ives and the anonymous reviewer as well as colleagues at the EastWest Center-Drs. Terry Rambo, Kirk Smith, and Michael Dove-were also helpful.

Gilmour, D. H., 1989: Forest resources and indigenous management in Nepal. Working Paper No. 17. Environment and Policy Institute, East-West Center, Honolulu.

1991: Trends in forest resources and management in the middle mountains of Nepal. In Shah, P., Schreier, H., Brown, S., and Riley, K., (eds.), Soil Fertility and Erosion Issues in the Middle Mountains of Nepal. Department of Soil Science, University of British Columbia, Varicouver.

Gilmour, D. H. and Fisher, R. J., 1991: Villagers, Forests and Foresters: The Philosophy, Process and Practice of Community Forestry in Nepal. Sahaygoi Press, Kathmandu.

Grainger; A., 1986: The future role of the tropical rain forests in the world forest economy. Ph.D. thesis, Oxford University.

Hoffpauir, R, 1978: Subsistence strategies and ecological consequences in the Nepal Himalaya. Anthropos, 73: 215-252.

Ives, J. D. and Messerli, B., 1989: The Himalayan Dilemma: Reconciling Development and Conservation. Routledge, London and New York.

Messerschmidt, D., 1990: Indigenous environmental management and adaptation: An introduction to four case studies from Nepal. Mountain Research and Development, 10(1): 3-4.

NAFP, 1979: Nepal's National Forestry Plan 1976 (2033). Unofticial English translation, Nepal-Australia Forestry Project, Kathmandu, Nepal.

Panayotou, T and Sungsuwan, S., 1989: An economic study of the causes of tropical deforestation: The case of Northeast Thailand-Discussion paper, Harvard Institute of International Development, Cambridge.

Stainton, J. D. A., 1972: Forests of Nepal. Haftner, New York.

Stone, L., 1990. Conservation and human resources: Comments on four case studies from Nepal. Mouniain Research and Development; $10(1)$; 5-6.

Thompson, M. and Warburton, M., 1985: Uncertainty on a Himalayan Scale. Mountain Research and Development, 5(2): $115-135$.

Wittfogel, K A., 1957: Oriental Despotism: A Comparative Study of Total Power. Yale University Press, New Haven. 